\title{
Management of shoot fly Atherigona soccata (Rondani) with different seed dressing chemicals
}

\author{
K. SRIDHAR, S. SRIDHARAN AND M. MUTHUKUMAR* \\ Department of Agricultural Entomology, Tamil Nadu Agricultural University, COIMBATORE (T.N.) INDIA
}

\section{ARITCLE INFO}

Received : 17.12 .2015

Revised : 26.02 .2016

Accepted : 07.03 .2016

\section{KEY WORDS :}

Sweet sorghum, Seed dressers, Germination, Shoot fly, Efficacy

*Corresponding author:

Email: muthukumar.tnau@ gmail.com

\begin{abstract}
This investigation was carried out in Tamil Nadu Agricultural University, Coimbatore to test the bio efficacy of different seed dressing chemical on the management of sorghum shoot fly. The micro plot field experiments conducted in farm holdings at Chinnamatham palayam and Idikarai, Coimbatore District revealed the effectiveness of imidacloprid in checking shoot fly incidence by recording a mean minimum dead heart damage of 20 and 11 per cent in trial I and II, respectively. The experiments also showed maximum plant height of 39.2 and $39.7 \mathrm{~cm}$ in imidacloprid treated plots. In the laboratory, the assessment of seed dressing chemicals on the germination indicated maximum germination (92\%) of sweet sorghum seeds in imidacloprid treatment with maximum seedling vigour index (2401.2). Laboratory experiments showed no adverse effect of imidacloprid and thiamethoxam on seed germination.
\end{abstract}

How to view point the article : Sridhar, K., Sridharan, S. and Muthukumar, M. (2016). Management of shoot fly Atherigona soccata (Rondani) with different seed dressing chemicals. Internat. J. Plant Protec., 9(1) : 193-198. 